\title{
OPTIMALISASI PEMBERIAN PUPUK KANDANG SAPI DAN ARANG KAYU TERHADAP PERTUMBUHAN SALAM (Syzygium polyanthum (Wight) Walp.) PADA TANAH TERCEMAR OLI BEKAS
}

\author{
The Optimization of The Giving Cow Manure and Wood Charcoal to the Growth of \\ Salam (Syzygium polyanthum (Wight) Walp.) on Contaminated Soil by Used \\ Engine Oil
}

\author{
Basuki Wasis $^{1 *}$ dan Ronaldo H Naiborhu ${ }^{2}$
}

(Diterima 19 Maret 2021 /Disetujui 11 Juni 2021)

\begin{abstract}
Illegal disposal of used oil causes soil contamination which can damage and reduce the soil productivity. Planting salam (Syzygium polyanthum) with the addition of cow manure and wood charcoal is expected to improve the characteristics of soil that was contaminated by used oil. This study analyzed the effect of giving cow fertilizer and wood charcoal on the growth of salam and determining the optimal dose to increase the growth of salam on contaminated soil by used oil. This study used a factorial completely randomized design (CRD) with two factors; that is cow manure and wood charcoal and using $60 \mathrm{ml} / \mathrm{kg}$ of soil contaminated with used oil. This study shows that giving 90 gram of cow manure and 40 gram of wood charcoal gave the best response to total wet weight and root length. The application of 90 gram of cow manure and 20 gram of wood charcoal gave the best response to the diameter and application of 90 gram of cow manure gave the best response to the total dry weight of salam seeds. Giving cow manure and wood charcoal can also reduce the Pb content by 0,43 ppm.
\end{abstract}

Keywords: cow manure, Syzygium polyanthum, used oil, wood charcoal

\begin{abstract}
ABSTRAK
Pembuangan oli bekas secara ilegal menyebabkan pencemaran tanah yang dapat merusak dan menurunkan produktivitas tanah. Penanaman salam (Syzygium polyanthum) dengan penambahan pupuk kandang sapi dan arang kayu diharapkan dapat memperbaiki karakteristik tanah tercemar oli bekas. Tujuan penelitian ini adalah menganalisis pengaruh pemberian pupuk kandang sapi dan arang kayu terhadap pertumbuhan salam serta mengetahui dosis yang optimal untuk meningkatkan pertumbuhan salam pada tanah tercemar oli bekas. Penelitian ini menggunakan rancangan acak lengkap (RAL) faktorial dengan dua yaitu pupuk kandang sapi dan arang kayu dengan media tanah tercemar oli bekas pada konsentasi $60 \mathrm{ml} / \mathrm{kg}$. Hasil penelitian ini menunjukkan pemberian pupuk kandang sapi 90 gram dan arang kayu 40 gram memberikan respon terbaik pada berat basah total dan panjang akar. Pemberian pupuk kandang sapi 90 gram dan arang kayu 20 gram memberikan respon terbaik pada diameter dan pemberian pupuk kandang sapi 90 gram memberikan respon terbaik pada berat kering total bibit salam. Pemberian pupuk kandang sapi dan arang kayu juga dapat menurunkan kandungan unsur $\mathrm{Pb}$ sebesar 0,43 ppm.
\end{abstract}

Kata kunci: arang kayu, oli bekas, pupuk kandang sapi, Syzygium polyanthum

\footnotetext{
${ }^{1}$ Departemen Silvikultur, Fakultas Kehutanan dan Lingkungan, IPB University

* Penulis korespondensi:

e-mail: basuki_wasis@yahoo.com

${ }^{2}$ Mahasiswa Sarjana Departemen Silvikultur, Fakultas Kehutanan dan Lingkungan, IPB University
} 


\section{PENDAHULUAN}

Pencemaran lingkungan merupakan masalah yang selalu dihadapi oleh manusia yang berada didalam suatu lingkungan tertentu. Lingkungan dikatakan tercemar apabila telah terjadi perubahan akibat masuknya dan/atau dimasukkannya suatu bahan atau benda dalam tatanan lingkungan itu sehingga berbeda dengan tatanan aslinya (Sutanto 2001). Pencemaran ini dapat berupa pencemaran udara, pencemaran air dan pencemaran tanah. Pencemaran yang menjadi perhatian khusus pada bidang kehutanan dan pertanian adalah pencemaran tanah. Pencemaran tanah terjadi saat adanya zat atau benda asing yang masuk dan tercampur ke dalam tanah sehingga mengubah kondisi awal pada keadaan yang lebih buruk. Salah satu bahan pencemaran tanah yang banyak tersebar diruang lingkup masyarakat adalah oli bekas pada kegiatan usaha bengkel kecil hingga besar yang tersebar di Indonesia.

Menurut Pitrandjalisari (2009), oli bekas merupakan salah satu kategori limbah bahan berbahaya dan beracun (B3) yang memiliki potensi untuk menimbulkan pencemaran dan kerusakan lingkungan. Hal tersebut karena oli bekas mengandung logam berat (Fe, $\mathrm{Pb}, \mathrm{Sn}, \mathrm{Cd}, \mathrm{Mn}, \mathrm{Zn}$ ) atau senyawa yang bersifat toksik seperti: Poly Chlorinated Biphenyls (PCBs) dan Polycyclic Aromatic Hydrocarbons (PAHs) (Welan et al. 2019). Logam dan senyawa ini dapat menimbulkan pencemaran saat tercecer atau tumpah ke tanah dan mengakibatkan matinya mikroba-mikroba yang berada di dalam tanah (Zam 2011). Keberadaan senyawa hidrokarbon dalam oli bekas tersebut dapat merubah struktur dan fungsi tanah sehingga produktivitas tanah menurun dan kehilangan unsur hara (Bano et al. 2020). Tanah yang tercemar oli biasanya berwarna hitam dan berminyak dengan bau oli yang menyengat (Yolantika et al. 2015).

Oli bekas tersebut sampai saat ini masih belum jelas pemanfaatannya sehingga penanganannya hanya sampai pada penyimpanan di dalam drum-drum (Prasaji et al. 2013). Limbah dari bengkel ini dapat diolah melalui proses fisik dan kimia tetapi membutuhkan biaya yang besar dan dapat menimbulkan polutan sekunder seperti formaldehida dan ozon. Oleh karena itu diperlukan metode alternatif yang lebih efektif, efisien, dan ramah lingkungan untuk mengatasi pencemaran tanah tersebut dengan proses biologi yaitu pemberian amelioran. Amelioran adalah bahan yang ditambahkan ke dalam tanah untuk memperbaiki sifat fisik, kimia dan biologi tanah, Amelioran bisa berasal dari bahan organik maupun anorganik (Wahyu dan Dewi 2019). Pemberian amelioran dimaksudkan sebagai sumber hara, mengurangi kemasaman tanah dan sumber pengikat atau penjerap kation-kation yang tercuci (Maftu'ah et al. 2013). Amelioran organik yang dapat digunakan seperti kompos, pupuk kandang sapi, abu kayu, arang sekam, arang kayu dan ampas tebu (Ramadhani et al. 2019). Pemberian pupuk kandang sapi sebagai amelioran dapat memperbaiki struktur tanah, menyediakan unsur hara dan pengurai bahan organik oleh mikro organisme tanah (Parnata 2010).
Kunci utama keberhasilan pembenahan tanah yang telah tercemar oli bekas melalui pemilihan jenis tanaman. Pemelihan vegetasi sebaiknya mempertimbangkan beberapa aspek seperti aspek ekologi dan fisiologis tanaman, aspek ekonomi dan aspek sosial. Salam (Syzygium polyanthum) merupakan salah satu jenis pohon serba guna yang berpeluang dikembangkan di lahan terdegradasi karena tidak membutuhkan persyaratan tumbuh yang tinggi dan jenis yang potensial untuk revegetasi lahan (Putri et al. 2019). Tanaman salam (Syzygium polyanthum) memiliki sistem perakaran yang kuat dan kokoh serta akar tunggang yang dilengkapi dengan rambut akar yang berperan dalam mencegah erosi dan mampu berperan sebagai menyerap logam berat dalam jumlah yang besar sehingga cocok untuk pembersihan tanah yang terkontaminasi logam berat (Lutfiasari dan Dharmono 2018). Salam juga banyak digunakan sebagai bahan obat dan pelengkap pada bumbu masakan. Penelitian ini dilakukan untuk menganalisis pengaruh pemberian pupuk kandang sapi dan arang kayu terhadap pertumbuhan salam pada tanah tercemar oli bekas.

\section{METODE PENELITIAN}

\section{Waktu dan Tempat penelitian}

Penelitian ini dilaksanakan pada bulan Februari hingga Juni 2020 di rumah kaca bagian Silvikultur dan Laboratorium Pengaruh Hutan, Departemen Silvikultur Fakultas Kehutanan dan Lingkungan IPB. Lokasi pengambilan sampel tanah untuk media penelitian dilakukan di belakang Teaching Laboratorium, Kampus IPB Dramaga, Jawa Barat. Analisis tanah dilakukan di Laboratorium Departemen Ilmu Tanah dan Sumber daya Lahan Fakultas Pertanian IPB.

\section{Alat dan Bahan}

Alat yang digunakan dalam penelitian ini adalah cangkul, karung, plastik, gelas ukur, timbangan, spidol permanen, sarung tangan, masker, polibag ukuran $20 \times$ $20 \mathrm{~cm}$, penggaris, digital calliper, gembor, semprotan, timbangan digital, tallysheet, alat tulis, kertas bekas, gunting, stapler, oven, kalkulator, toples platik, botol film, gelas erlenmeyer, buret digital, pipet, label, kamera, laptop, software Microsoft Excel 2007, software Microsoft Word 2010, dan software SAS 9.1. Bahan yang digunakan dalam penelitian ini adalah salam (Syzygium polyanthum) berumur \pm 4 bulan yang diambil dari Persemaian Permanen IPB, media tanam berupa tanah, pupuk kandang sapi, arang kayu yang telah dihancurkan dengan ukuran sebesar $\pm 5 \mathrm{~cm}$, oli bekas, pestisida, air, larutan $\mathrm{KOH} 0,1 \mathrm{~N}, \mathrm{HCl} 0,1 \mathrm{~N}$, indikator phenolphthalein dan metil orange.

\section{Prosedur Penelitian}

Penelitian dilaksanakan melalui beberapa tahapan yaitu: 


\section{Persiapan}

Tahapan awal yang dilakukan adalah persiapan. Persiapan dimulai dengan pengumpulan bibit, pengambilan media tanam berupa tanah dan penyiapan peralatan yang dibutuhkan. Bibit yang digunakan adalah bibit salam yang diambil dari Persemaian Permanen IPB dengan kondisi bibit yang sehat, berbatang lurus, dengan diamater $\pm 0,3 \mathrm{~cm}$ dan tinggi $\pm 25 \mathrm{~cm}$, serta bebas dari hama dan penyakit. Media yang digunakan adalah tanah yang pucuk (top soil) sedalam $20 \mathrm{~cm}$ yang berasal dari Belakang TL, Kampus IPB Dramaga. Tanah yang telah diambil dibersihkan dari kotoran serasah yang tersisa dan diamkan di rumah kaca dalam keadaan terbuka dengan tujuan agar tanah menjadi kering udara. Tanah yang telah kering udara ditimbang sebanyak $1 \mathrm{~kg}$ dan dimasukkan kedalam plastik. Tanah yang telah ditimbang dikompositkan dengan oli bekas sebanyak $60 \mathrm{ml}$ sehingga membuat kondisi tanah tercemar oli bekas. Tanah diaklimatisasi selama satu minggu bertujuan agar oli dapat meresap dan bercampur dengan baik pada tanah. Tanah yang telah tercemar dan diaklimatisasi selama satu minggu diberikan perlakuan dengan mencampurkan pupuk kandang sapi dan arang kayu sesuai dengan dosis yang telah ditentukan. Media tanam yang telah tercampur dengan perlakuan selanjutnya diaklimatisasi kembali selama satu minggu dan dimasukkan ke dalam polybag sebagai media baru bagi bibit salam.

\section{Penyapihan}

Bibit salam disapih kedalam 60 polybag yang telah dipersiapkan pada tahap persiapan sebelumnya. Waktu penyapihan dilaksanakan pada pagi dan sore hari untuk menghindari terjadinya penguapan yang berlebihan. Bibit ditanam dengan mengikutsertakan tanahnya untuk menghindari kondisi stress pada bibit.

\section{Pemeliharaan}

Pemeliharaan dilakukan pada bibit salam yang telah disapih dan ditempatkan dalam rumah kaca salama 15 minggu. Pemeliharaan bibit yakni penyiraman secara rutin setiap hari pada pagi dan sore hari. Kegiatan penyiraman mempertimbangkan kondisi media tanam di polybag. Penyiangan dilakukan seperlunya jika terdapat tumbuhan pengganggu bibit. Pengendalian hama dan penyakit dilakukan dengan penyemprotan pestisida pada bibit salam.

\section{Pengamatan dan pengambilan data}

Pengambilan data didasarkan pada pengamatan dilakukan selama proses pemeliharaan berlangsung yaitu selama 15 minggu. Parameter yang diukur selama pengambilan data yaitu yaitu tinggi, diameter, berat basah total, berat kering total, panjang akar, nisbah pucuk akar, uji respirasi dan analisis sifat kimia tanah.

\section{Tinggi bibit}

Pengambilan data petumbuhan tinggi bibit salam dilakukan seminggu sekali yang dimulai setelah tahap penyapihan sampai 15 minggu pengamatan. Pengukuran tinggi bibit menggunakan penggaris dengan dimulai dari pangkal batang hingga titik tumbuh pucuk apikal.
Pengambilan data petumbuhan diamater bibit salam dilakukan seminggu sekali yang dimulai setelah tahap penyapihan sampai 15 minggu pengamatan. Pengukuran diameter bibit menggunakan digital calliper pada pangkal batang yang telah ditandai.

\section{Berat Basah Total}

Pengukuran berat basah total dilakukan pada akhir pengamatan. Bibit salam yang telah dipanen dipisahkan antara bagian akar dan pucuk (daun dan batang disatukan). Kemudian masing-masing ditimbang dengan menggunakan timbangan digital. Berat basah total merupakan penjumlahan antara berat basah akar dan berat basah pucuk.

\section{Berat Kering Total}

Pengukuran berat kering total dilakukan setelah bagian tanaman yang terdiri dari bagian akar dan pucuk (daun dan batang) dioven pada suhu $80^{\circ} \mathrm{C}$ selama 24 jam. Selanjutnya, kedua bagian tersebut ditimbang dengan timbangan digital. Berat kering total diperoleh dari penjumlahan berat kering akar dengan berat kering pucuk.

\section{Nisbah Pucuk Akar (NPA)}

NPA dapat ditentukan dengan perbandingan nilai berat kering total pucuk dengan nilai kering total akar.

\section{Panjang Akar}

Pengukuran panjang akar dilakukan pada akhir pengamatan. Bibit salam yang telah dipanen pada waktu bersamaan panjang akar diukur dengan menggunakan penggaris yang dimulai dari leher akar hingga bagian akar paling ujung.

\section{Uji Respirasi}

Pengukuran dan pengujian respirasi tanah (jumlah $\mathrm{CO}_{2}$ ) dilakukan dengan menimbang 100 gram media tanam pada akhir pengamatan. Menyiapkan larutan KOH 0,1 N sebanyak $5 \mathrm{ml}$ dan aquades sebanyak $10 \mathrm{ml}$ yang selanjutnya dimasukkan kedalam botol film yang tersedia. Tanah yang telah ditimbang dimasukkan kedalam toples plastik kedap udara bersama dengan 2 botol film berisi $5 \mathrm{ml}$ aquades dan $10 \mathrm{ml} \mathrm{KOH} 0,1 \mathrm{~N}$ lalu diinkubasi selama 3 hari. Setelah inbukasi selesai, botol film berisi $\mathrm{KOH}$ dikeluarkan dari toples dan kemudian ditetesi indikator phenolphthalein sebanyak 2 tetes sehingga warnanya berubah menjadi merah muda, kemudian dititrasi dengan larutan $\mathrm{HCl}$ menggunakan digital burette sampai berwarna bening. Larutan ditambahkan 2 tetes indikator metil orange sehingga larutan berwarna kuning, kemudian dititrasi kembali dengan larutan $\mathrm{HCl}$ hingga berwarna merah muda, dan dicatat angka yang tertera pada digital burette untuk menghitung jumlah $\mathrm{CO}_{2}$ dengan menggunakan persamaan:

$$
\mathrm{CO}_{2}(\text { gram tanah } / \text { hari })=\frac{(a-b) \times t \times 120}{n}
$$

$$
\text { Keterangan: }
$$

$\mathrm{a}=\mathrm{ml} \mathrm{HCl}$ untuk sampel media tanam

$\mathrm{b}=\mathrm{ml} \mathrm{HCl}$ untuk blanko

$\mathrm{t}=$ normalitas $\mathrm{HCl}$ yang digunakan $(0,1 \mathrm{~N})$

$\mathrm{n}$ = lama hari inkubasi

\section{Diameter bibit}




\section{Analisis Tanah}

Analisis tanah dilakukan pada awal pengamatan dan akhir pengamatan. Pada awal pengamatan menggunakan tanah kontrol yang diberikan cemaran oli bekas sebanyak $60 \mathrm{ml}$ pada tanah $1000 \mathrm{~g}$. Pada akhir pengamatan menggunakan tanah yang memberikan respon terbaik selama pengamatan berlangsung. Analisis dilakukan di Laboratorium Departemen Ilmu Tanah dan Sumberdaya Lahan, Fakultas Pertanian IPB.

\section{Rancangan Percobaan}

Rancangan percobaan yang digunakan dalam penelitian ini adalah rancangan acak lengkap (RAL) faktorial dengan dua faktor. Faktor pertama, yaitu pupuk kandang sapi yang terdiri dari 5 taraf. Faktor kedua, yaitu arang kayu yang terdiri dari 4 taraf. Masing-masing taraf perlakuan terdiri dari 3 ulangan, . Selain itu, masing-masing faktor dirinci sebagai berikut: Faktor pemberian pupuk kandang sapi $(\mathrm{K})$, terdiri dari: $\mathrm{K} 0=0$ gram (pupuk kandang sapi) $+1000 \mathrm{~g}$ (tanah tercemar oli bekas), K1 = 30 gram (pupuk kandang sapi $)+1000 g$ (tanah tercemar oli bekas), K2 = 60 gram (pupuk kandang sapi) + 1000 gram (tanah tercemar oli bekas), K3 = 90 gram (pupuk kandang sapi) + 1000g (tanah tercemar oli bekas), K4= 120 gram (pupuk kandang sapi) + 1000 gram (tanah tercemar oli bekas), Faktor pemberian arang kayu (A), terdiri dari: $\mathrm{A} 0=0$ gram (arang kayu) + 1000 gram (tanah tercemar oli bekas $), \mathrm{A} 1=20$ gram $($ arang kayu $)+1000 \mathrm{~g}($ tanah tercemar oli bekas), A2 $=40$ gram (arang kayu) $+1000 \mathrm{~g}$ (tanah tercemar oli bekas), A3 = 60 gram (arang kayu) + $1000 \mathrm{~g}$ (tanah tercemar oli bekas).

\section{Analisis Data}

Pengujian sidik ragam dengan uji $\mathrm{F}$ dilakukan untuk mengetahui pengaruh perlakuan dalam penelitian ini. Data diolah menggunakan software SAS 9.1. Perlakuan berpengaruh nyata jika nilai $\mathrm{F} \leq 0,05$. Uji lanjut nilai tengah dilakukan dengan menggunakan prosedur Uji lanjut Duncan's Multiple Range Test.

\section{HASIL DAN PEMBAHASAN}

Perkembangan tanaman meliputi pertumbuhan dan diferensiasi. Masa pertumbuhan merupakan masa perkembangan yang progresif dari suatu organisme yang bersifat kuantitatif dan irreversible serta suatu koordinasi dari banyak peristiwa dan berlangsung pada tahap yang berbeda, yaitu dari tahap biofisika dan biokimia ke tahap organisme yang utuh dan lengkap (Oktavian et al. 2019; Harahap 2012). Pertumbuhan tanaman sering ditentukan dengan cara mengukur pembesaran kesatu atau dua arah dan dapat didefinisikan sebagai respon fisiologi yang diketahui dengan adanya perubahan tinggi, diameter, berat basah total, berat kering total, nisbah pucuk akar, panjang akar dan respirasi tanah (jumlah $\mathrm{CO}_{2}$ ). Respon tersebut menjadi parameter yang digunakan untuk mengetahui pertumbuhan dan perkembangan bibit salam (Syzygium polyanthum) yang media tanamnya tercemar oli bekas dengan penambahan pupuk kandang sapi dan arang kayu. Hasil pengamatan terhadap parameter tersebut dapat diketahui melalui rekapitulasi sidik ragam yang disajikan dalam Tabel 1.

Hasil sidik ragam pada Tabel 1 menunjukkan bahwa pemberian pupuk kandang sapi tunggal berpengaruh nyata terhadap parameter diamater, berat basah total, berat kering total dan panjang akar bibit salam. Pemberian arang kayu tunggal berpengaruh nyata terhadap parameter berat basah total bibit salam. Interaksi antara pemberian pupuk kandang sapi dan arang kayu berpengaruh nyata terhadap parameter diamater, berat basah total dan panjang akar bibit salam. Sementara itu, pemberian pupuk kandang sapi tunggal, arang kayu tunggal dan interaksi pupuk kandang sapi dan arang kayu tidak memberikan pengaruh nyata pada parameter tinggi, nisbah pucuk akar dan respirasi tanah (jumlah $\mathrm{CO}_{2}$ ) bibit salam

\section{Pertumbuhan Tinggi Bibit Salam}

Hasil sidik ragam yang ditunjukkan pada Tabel 1 menyatakan bahwa pemberian pupuk kandang sapi tunggal, arang kayu tunggal dan interaksi pupuk kandang sapi dan arang kayu tidak memberikan pengaruh nyata terhadap pertumbuhan tinggi bibit salam.

Tabel 1 Rekapitulasi sidik ragam pemberian pupuk kandang sapi dan arang kayu terhadap pertumbuhan bibit salam

\begin{tabular}{lccc}
\hline \multirow{2}{*}{ Parameter } & \multicolumn{2}{c}{ Perlakuan } \\
\cline { 2 - 4 } & $\begin{array}{c}\text { Pupuk kandang } \\
\text { sapi }\end{array}$ & Arang kayu & $\begin{array}{c}\text { Pupuk kandang sapi X } \\
\text { Arang kayu }\end{array}$ \\
\hline Tinggi & $0,6717^{\text {tn }}$ & $0,6798^{\text {tn }}$ & $0,8736^{\text {th }}$ \\
Diameter & $0,0015^{*}$ & $0,2976^{\text {tn }}$ & $0,0117^{*}$ \\
Berat basah total & $0,0391^{*}$ & $0,1467^{\text {tn }}$ & $0,0269^{*}$ \\
Berat kering total & $0,0096^{*}$ & $0,2943^{\text {tn }}$ & $0,9526^{\text {tn }}$ \\
Nisbah pucuk akar & $0,5144^{\text {tn }}$ & $0,8650^{\text {tn }}$ & $0,9445^{\text {tn }}$ \\
Panjang akar & $0,0112^{*}$ & $<, 0001^{*}$ & $0,0027^{*}$ \\
Respirasi tanah & $0,1535^{\text {tn }}$ & $0,6382^{\text {tn }}$ & $0,2572^{\text {tn }}$ \\
\hline
\end{tabular}

\footnotetext{
Keterangan:

$*$ = perlakuan berpengaruh nyata pada selang kepercayaan $95 \%$

tn =perlakuan tidak berpengaruh nyata
} 
Haase (2008) melaporkan bahwa pengukuran pertumbuhan berupa tinggi dan diameter bibit merupakan variabel yang sering digunakan dalam menentukan mutu bibit suatu tanaman. Pemberian pupuk kandang sapi tunggal, arang kayu tunggal dan interaksi pupuk kandang sapi dan arang kayu tidak memberikan pengaruh nyata pada pertumbuhan tinggi bibit salam. Hal tersebut dikarena pertumbuhan tinggi bibit salam setiap minggunya tidak menunjukkan perbedaan yang signifikan.

\section{Pertumbuhan Diameter Bibit Salam}

Pertumbuhan ke samping (diameter) disebut dengan istilah pertumbuhan sekunder (secondary growth). Pertumbuhan sekunder pada batang menunjukkan aktivitas xilem dan pembesaran sel yang sedang tumbuh. aktivitas pada batang tersebut menyebabkan kambium terdorong keluar sehingga terbentuk sel baru di luar lapisan tersebut dan akhirnya peningkatan diameter tanaman (Riyanto et al. 2013). Hasil sidik ragam yang ditunjukkan pada Tabel 2 menyatakan bahwa pemberian pupuk kandang sapi tunggal dan interaksi pupuk kandang sapi dan arang kayu memberikan pengaruh nyata terhadap parameter pertumbuhan diameter pada bibit salam sedangkan pemberian arang kayu tunggal tidak memberikan pengaruh nyata pada parameter pertumbuhan diamater pada bibit salam. Hasil uji Duncan pengaruh pemberian pupuk kandang sapi dan arang kayu terhadap

Tabel 2 Pengaruh pemberian pupuk kandang sapi dan arang kayu terhadap pertumbuhan diamater bibit salam

\begin{tabular}{lcc}
\hline Perlakuan & $\begin{array}{c}\text { Diameter } \\
(\mathrm{mm})\end{array}$ & \% Perubahan \\
\hline K3A1 & $3,433 \mathrm{a}$ & 51,47 \\
K3A2 & $3,133 \mathrm{ab}$ & 38,23 \\
K2A2 & $3,100 \mathrm{ab}$ & 36,76 \\
K1A0 & $3,067 \mathrm{ab}$ & 35,29 \\
K2A0 & $3,033 \mathrm{ab}$ & 33,82 \\
K3A0 & $2,933 \mathrm{abc}$ & 29,41 \\
K4A1 & $2,867 \mathrm{abc}$ & 26,47 \\
K2A3 & $2,833 \mathrm{abcd}$ & 25,00 \\
K4A0 & $2,767 \mathrm{abcd}$ & 22,06 \\
K3A3 & $2,767 \mathrm{abcd}$ & 22,06 \\
K0A2 & $2,733 \mathrm{abcd}$ & 20,58 \\
K1A3 & $2,700 \mathrm{abcd}$ & 19,12 \\
K4A2 & $2,633 \mathrm{bcd}$ & 16,17 \\
K0A3 & $2,400 \mathrm{bcd}$ & 5,88 \\
K4A3 & $2,267 \mathrm{~cd}$ & 0,00 \\
K0A0 & $2,267 \mathrm{~cd}$ & 0,00 \\
K0A1 & $2,233 \mathrm{~cd}$ & $-1,47$ \\
K1A1 & $2,200 \mathrm{~cd}$ & $-2,94$ \\
K2A1 & $2,200 \mathrm{~cd}$ & $-2,94$ \\
K1A2 & $2,100 \mathrm{~cd}$ & $-7,35$ \\
\hline Ked
\end{tabular}

Keterangan: Angka yang diikuti oleh huruf yang sama menunjukkan perlakuan tidak berbeda nyata pada selang kepercayaan $95 \%$. pertumbuhan diamater bibit salam pada tanah tercemar oli bekas dapat dilihat pada Tabel 2 .

Berdasarkan hasil uji Duncan pengaruh pemberian pupuk kandang sapi dan arang kayu terhadap pertumbuhan diamater bibit salam yang terdapat pada Tabel 2, menunjukkan bahwa dosis perlakuan K3A1 (pupuk kandang sapi 90 gram dan arang kayu $20 \mathrm{~g}$ ) memberikan hasil terbaik sebesar $3,433 \mathrm{~mm}$ dengan persentase perubahan hingga $51,47 \%$ dari perlakuan kontrol. Hal tersebut mengindikasi bahwa dosis perlakuan K3A1 (pupuk kandang sapi 90 gram dan arang kayu $20 \mathrm{~g}$ ) merupakan dosis yang tepat dalam meningkatkan pertumbuhan diameter pada bibit salam. Dosis perlakuan tersebut juga tidak berbeda nyata dengan beberapa perlakuan lainnya yang diikuti notasi a yang berada pada nilai besar pertambahan diameter bibit salam. Hal tersebut dikarenakan interaksi antara pupuk kandang sapi dan arang kayu dapat memberikan kondisi media tumbuh yang baik bagi bibit salam. Kandungan unsur hara yang ada pada pupuk kandang sapi dan arang kayu dapat memicu pertumbuhan diamater yang baik pada bibit salam.

\section{Berat Basah Total dan Berat Kering Total Bibit Salam}

Berat basah tanaman merupakan indikator untuk mengetahui kadar dan kebutuhan air dari suatu tanaman. Berat basah juga dapat menunjukkan hasil aktivitas metabolik dan menggambarkan aktivitas metabolisme suatu tanaman, karena berkaitan dengan keberadaan unsur hara dan kadar pada tanaman (Sitompul dan Guritno 1995). Hasil sidik ragam yang ditunjukkan pada Tabel 3 menyatakan bahwa pemberian pupuk kandang sapi tunggal memberikan pengaruh nyata terhadap parameter berat kering total pada bibit salam sedangkan pemberian arang kayu tunggal dan interaksi pupuk kandang sapi dan arang kayu tidak memberikan pengaruh nyata terhadap parameter berat kering total bibit salam pada tanah tercemar oli bekas.

Hasil uji Duncan pengaruh pemberian pupuk kandang sapi tunggal terhadap berat kering total bibit salam pada tanah tercemar oli bekas dapat dilihat pada Tabel 3. Tabel 3 memperlihatkan bahwa pemberian pupuk kandang sapi tunggal memberikan pengaruh nyata terhadap berat kering total bibit salam. Perlakuan K3 (90 gram) pupuk kandang sapi mampu meningkatkan berat kering total bibit salam dari

Tabel 3. Hasil uji Duncan pengaruh pemberian pupuk kandang sapi terhadap berat kering total bibit salam

\begin{tabular}{lcc}
\hline Perlakuan & $\begin{array}{c}\text { Berat kering } \\
\text { total }(\mathrm{g})\end{array}$ & \% Perubahan \\
\hline $\mathrm{K} 3$ & $11,074 \mathrm{a}$ & 51,80 \\
$\mathrm{~K} 1$ & $9,731 \mathrm{ab}$ & 33,39 \\
$\mathrm{~K} 4$ & $8,570 \mathrm{~b}$ & 17,48 \\
$\mathrm{~K} 2$ & $7,707 \mathrm{~b}$ & 5,65 \\
$\mathrm{~K} 0$ & $7,295 \mathrm{~b}$ & 0,00 \\
\hline
\end{tabular}

Keterangan: Angka yang diikuti oleh huruf yang sama menunjukkan perlakuan tidak berbeda nyata pada selang kepercayaan $95 \%$. 
perlakuan kontrol hingga 51,80\%. Perlakuan Perlakuan K3 (90 gram) pupuk kandang sapi juga tidak berbeda nyata dengan perlakuan K1 (30 gram) pupuk kandang sapi. Sementara perlakuan yang memiliki nilai terendah adalah kontrol dengan berat kering total 7,295 gram. Perlakuan kontrol jika dilihat melalui uji Duncan tidak berbeda nyata dengan perlakuan K2 (60 gram), K4 (120 gram) dan K1 (30 gram) pupuk kandang sapi. Hal tersebut mengindikasikan bahwa pemberian 90 gram pupuk kandang sapi mampu meningkatkan berat kering total bibit salam daripada perlakuan pupuk kandang sapi tunggal lainnya sehingga tidak perlu mengeluarkan biaya yang lebih terkait ketersedian pupuk kandang sapi dalam menunjang peningkatan berat kering total bibit salam.

Hasil uji Duncan pengaruh pemberian pupuk kandang sapi dan arang kayu terhadap berat basah total bibit salam pada tanah tercemar oli bekas dapat dilihat pada Tabel 4. Berdasarkan hasil yang terlihat pada Tabel 4, bahwa perlakuan pemberian pupuk kandang sapi dan arang kayu berpengaruh nyata terhadap berat basah total bibit salam. Perlakuan yang memiliki hasil terbaik adalah perlakuan K3A2 (pupuk kandang sapi 90 gram dan arang kayu $40 \mathrm{~g}$ ) dengan persentase perubahan hingga $86,92 \%$ dari perlakuan kontrol. Perlakuan K3A2 (pupuk kandang sapi 90 gram dan arang kayu $40 \mathrm{~g}$ ) juga memberikan hasil yang tidak berbeda nyata dengan beberapa perlakuan lainnya. Sementara, hasil terendah pada berat basah bibit salam terdapat pada perlakuan kontrol. Hal tersebut menunjukkan bahwa pemberian pupuk kandang sapi dan arang kayu dengan dosis perlakuan K3A2 (pupuk kandang sapi 90 gram dan arang kayu 40 g)

Tabel 4. Hasil uji Duncan pengaruh pemberian pupuk kandang sapi dan arang kayu terhadap berat basah total bibit salam

\begin{tabular}{lcc}
\hline Perlakuan & $\begin{array}{c}\text { Berat basah } \\
\text { total }(\mathrm{g})\end{array}$ & $\%$ Perubahan \\
\hline K3A2 & $30,180 \mathrm{a}$ & 86,91 \\
K2A0 & $27,053 \mathrm{ab}$ & 67,54 \\
K1A2 & $25,890 \mathrm{abc}$ & 60,34 \\
K4A0 & $24,303 \mathrm{abcd}$ & 50,51 \\
K3A1 & $22,913 \mathrm{bcde}$ & 41,90 \\
K4A1 & $22,490 \mathrm{bcde}$ & 39,28 \\
K2A1 & $22,263 \mathrm{bcde}$ & 37,88 \\
K2A3 & $21,987 \mathrm{bcde}$ & 36,17 \\
K1A1 & $21,917 \mathrm{bcde}$ & 35,73 \\
K0A2 & $21,867 \mathrm{bcde}$ & 35,42 \\
K3A0 & $21,863 \mathrm{bcde}$ & 35,40 \\
K1A3 & $20,483 \mathrm{bcde}$ & 26,85 \\
K3A3 & $20,357 \mathrm{bcde}$ & 26,07 \\
K4A2 & $20,133 \mathrm{bcde}$ & 24,69 \\
K1A0 & $19,813 \mathrm{bcde}$ & 22,70 \\
K0A1 & $19,737 \mathrm{bcde}$ & 22,23 \\
K4A3 & $19,430 \mathrm{cde}$ & 20,33 \\
K2A2 & $18,170 \mathrm{de}$ & 12,53 \\
K0A3 & $17,827 \mathrm{de}$ & 10,40 \\
K0A0 & $16,147 \mathrm{e}$ & 0,00 \\
\hline
\end{tabular}

Keterangan: Angka yang diikuti oleh huruf yang sama menunjukkan perlakuan tidak berbeda nyata pada selang kepercayaan $95 \%$. menghasilkan berat basah total yang paling optimal. Perpaduan pupuk kandang sapi dan arang kayu mampu menyediakan unsur hara yang dibutuhkan bibit salam selama pertumbuhannya.

Akumulasi rata-rata berat basah total dan berat kering total pada berbagai dosis perlakuan disajikan pada Gambar 1. Pada Gambar 1 dapat dilihat bahwa dari kedua parameter perlakuan K3A2 (pupuk kandang sapi 90 gram dan arang kayu 40 g) memberikan nilai tertinggi dari perlakuan lainnya. Berat basah dan berat kering bibit salam pada berbagai perlakuan memiliki hasil yang beragam. Hal ini menunjukkan bahwa setiap tanaman memiliki respon yang berbeda-beda yang dipengaruhi oleh toleransi masing-masing jenis tanaman berdasarkan faktor genetiknya, daya adaptasi tumbuhan terhadap media tanam berbeda-beda (Fitriyah et al. 2017). Unsur hara pada media tumbuh yang cukup dan seimbang merupakan faktor penting dalam menunjang pertumbuhan tanaman.

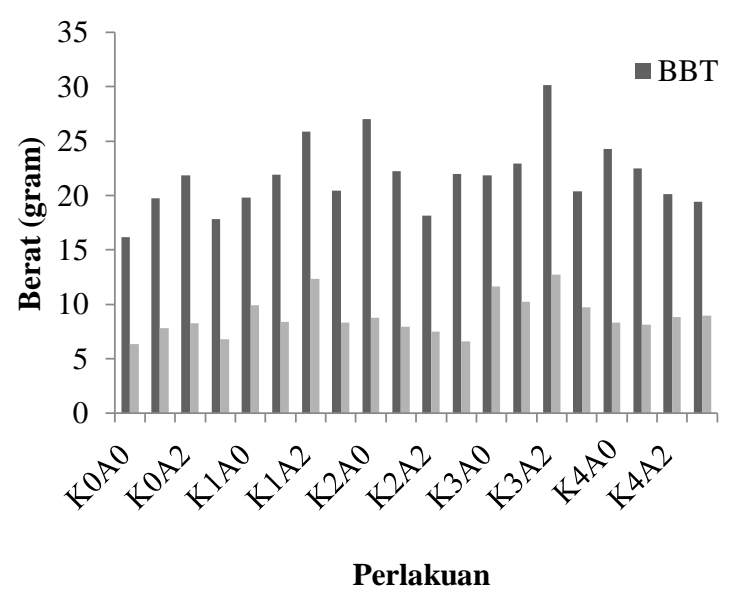

Gambar 1 Rata-rata berat basah total (BBT) dan berat kering total (BKT) bibit salam pada berbagai dosis perlakuan penambahan pupuk kandang sapi dan arang kayu

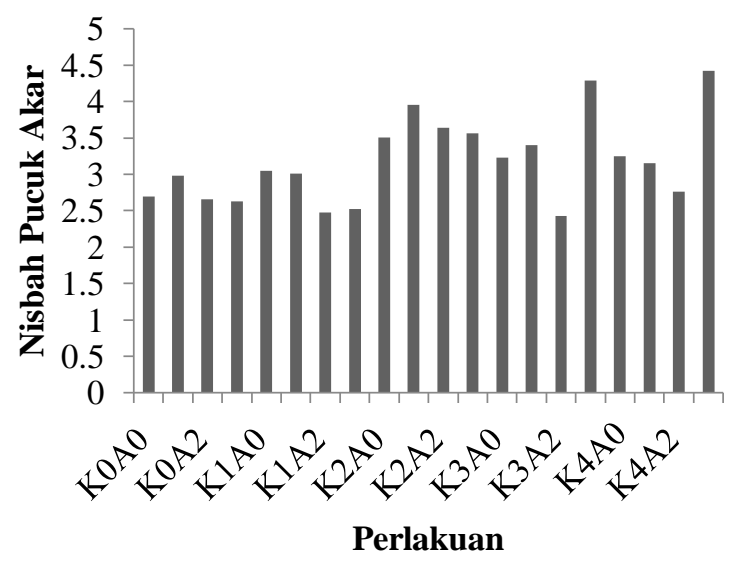

Gambar 2 Rata-rata nisbah pucuk akar (NPA) bibit salam pada berbagai dosis perlakuan penambahan pupuk kandang sapi dan arang kayu 


\section{Nisbah Pucuk Akar Bibit Salam}

Menurut Fandeli (2000) dalam Hasibuan et al. (2018) besaran nilai nisbah pucuk akar dapat memperlihatkan kondisi fisiologi suatu tanaman. Besar kecilnya nilai nisbah pucuk akar dapat digunakan sebagai parameter untuk mengetahui kondisi fisik tanaman dalam ketahanan tanaman bila dipindah ke lapang. Hasil sidik ragam yang ditunjukkan pada Tabel 2 menyatakan bahwa pemberian pupuk kandang sapi tunggal, arang kayu tunggal dan interaksi pupuk kandang sapi dan arang kayu tidak memberikan pengaruh nyata terhadap nisbah pucuk akar (NPA) bibit salam pada tanah tercemar oli bekas. Hal tersebut dapat dipengaruh oleh berbagai faktor baik faktor internal bibit salam dan faktor eksternal pada kualitas tempat tembuhnya. Rata-rata nisbah pucuk akar (NPA) bibit salam pada berbagai dosis perlakuan dapat dilihat pada Gambar 2.

Nilai NPA yang tinggi menunjukkan pertumbuhan bagian pucuk tanaman lebih tinggi dibandingkan dengan pertumbuhan akarnya dan sebaliknya nilai NPA yang rendah menunjukkan pertumbuhan bagian pucuk lebih rendah dibanding pertumbuhan akar. Nilai NPA yang baik berada pada kisaran angka 1-3, namun semakin mendekati nilai angka 1 maka pertumbuhan dan kemampuan hidup tanaman menunjukkan hasil terbaik (Duryea dan Brown 1984 dalam Bramasto et al. 2011). Gambar 2 memperlihatkan sebaran nilai nisbah pucuk akar pada bibit salam. Nilai yang dihasilkan oleh berbagai perlakuan sekisar antara 2,43-4,42. Hal tersebut mengindikasikan pertumbuhan bibit salam jika dilihat dari parameter NPA belum optimal. Jika dilihat

Tabel 5 Hasil uji Duncan pengaruh pemberian pupuk kandang sapi dan arang kayu terhadap panjang akar bibit salam

\begin{tabular}{lcc}
\hline Perlakuan & $\begin{array}{c}\text { Panjang akar } \\
(\mathrm{cm})\end{array}$ & \% Perubahan \\
\hline K3A2 & $37,733 \mathrm{a}$ & 120,66 \\
K2A2 & $34,300 \mathrm{ab}$ & 100,58 \\
K4A3 & $31,600 \mathrm{abc}$ & 84,80 \\
K4A2 & $30,067 \mathrm{bcd}$ & 75,83 \\
K2A0 & $26,667 \mathrm{cde}$ & 55,95 \\
K1A2 & $26,600 \mathrm{cde}$ & 55,56 \\
K0A2 & $26,433 \mathrm{cde}$ & 54,58 \\
K2A3 & $26,400 \mathrm{cde}$ & 54,39 \\
K3A0 & $25,867 \mathrm{cde}$ & 51,27 \\
K4A0 & $25,733 \mathrm{cde}$ & 50,49 \\
K0A1 & $25,200 \mathrm{cde}$ & 47,37 \\
K1A3 & $24,100 \mathrm{def}$ & 40,94 \\
K2A1 & $23,333 \mathrm{def}$ & 36,45 \\
K1A0 & $22,967 \mathrm{def}$ & 34,31 \\
K0A3 & $21,733 \mathrm{ef}$ & 27,09 \\
K1A1 & $21,233 \mathrm{ef}$ & 24,17 \\
K3A1 & $21,067 \mathrm{ef}$ & 23,20 \\
K4A1 & $20,433 \mathrm{ef}$ & 19,49 \\
K3A3 & $19,237 \mathrm{ef}$ & 12,50 \\
K0A0 & $17,100 \mathrm{f}$ & 0,00 \\
\hline
\end{tabular}

Keterangan: Angka yang diikuti oleh huruf yang sama menunjukkan perlakuan tidak berbeda nyata. pada seluruh perlakuan yang memiliki nilai NPA tertinggi terdapat pada perlakuan K4A3 (pupuk kandang sapi 120 gram dan arang kayu $90 \mathrm{~g}$ ). Hal ini menunjukkan bahwa perlakuan tersebut memiliki pertumbuhan pucuk yang lebih dominan dari pada akarnya. Jika dilihat dari nilai NPA terkecil terdapat pada perlakuan K3A2 (pupuk kandang sapi 90 gram dan arang kayu $60 \mathrm{~g}$ ) yaitu sebesar 2,43. Nilai tersebut tergolong cukup optimal karena masih berada pada range 1-3. Hal tersebut membuktikan bahwa pemberian pupuk kandang sapi dan arang kayu pada bibit salam dapat mengoptimal pertumbuhan akar dan pucuk yang cukup seimbang sehingga hara dan air yang ada dapat digunakan dengan baik oleh bibit salam tersebut.

\section{Panjang Akar Bibit Salam}

Bagi tanaman akar merupakan faktor penting dalam pertumbuhan, tanpa adanya akar proses fotosintesis untuk memproduksi karbohidrat dan energi akan terhambat (Mahendra 2009). Hasil sidik ragam yang ditunjukkan pada Tabel 2 menyatakan bahwa pemberian pupuk kandang sapi tunggal, arang kayu tunggal dan interaksi pupuk kandang sapi dan arang kayu berpengaruh nyata terhadap pertumbuhan panjang akar pada bibit salam. Hasil uji Duncan pengaruh pemberian pupuk kandang sapi dan arang kayu terhadap pertumbuhan panjang akar bibit salam pada tanah tercemar oli bekas dapat dilihat pada Tabel 5 .

Berdasarkan Tabel 5, terlihat bahwa perlakuan yang memiliki hasil terbaik adalah perlakuan K3A2 (pupuk kandang sapi 90 gram dan arang kayu 40 g) dengan persentase perubahan hingga $120,66 \%$ dari perlakuan kontrol. Perlakuan K3A2 (pupuk kandang sapi 90 gram dan arang kayu $40 \mathrm{~g}$ ) juga memberikan hasil yang tidak berbeda nyata dengan beberapa perlakuan lainnya. Sementara, hasil terkecil berada pada perlakuan kontrol dengan tidak adanya penambahan pupuk kandang sapi ataupun arang kayu. Hal tersebut menunjukkan bahwa interaksi pupuk kandang sapi dan arang kayu terkhusus dengan dosis perlakuan K3A2 (pupuk kandang sapi 90 gram dan arang kayu $40 \mathrm{~g}$ ) dapat memberikan media tumbuh yang baik sehingga memberikan hasil yang paling optimal terhadap penambahan panjang akar bibit salam.

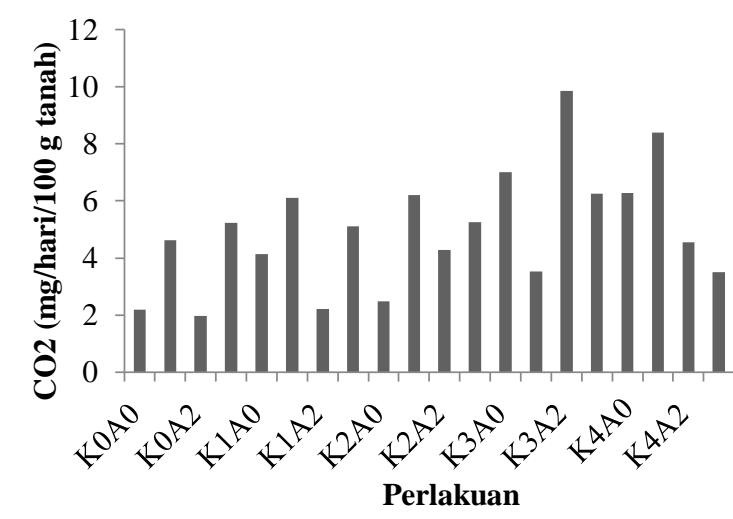

Gambar 3 Respirasi tanah pada media salam pada berbagai dosis perlakuan penambahan pupuk kandang sapi dan arang kayu 


\section{Respirasi Tanah}

Respirasi pada tanah dapat didefinisikan sebagai penggunaan $\mathrm{O}_{2}$ atau pelepasan $\mathrm{CO}_{2}$ oleh fungi, bakteri, protozoa, dan alga yang melibatkan pertukaran gas dalam proses metabolisme aerob (Anderson 1982 dalam Setiawan et al. 2016). Hasil sidik ragam yang ditunjukkan pada Tabel 2 menyatakan bahwa pemberian pupuk kandang sapi tunggal, arang kayu tunggal dan interaksi pupuk kandang sapi dan arang kayu tidak memberikan pengaruh nyata terhadap nilai respirasi tanah (jumlah $\mathrm{CO}_{2}$ ) pada tanah tercemar oli bekas. Respirasi tanah media tanam bibit salam pada berbagai dosis perlakuan terlihat pada Gambar 3.

Hasil uji respirasi tanah pada seluruh dosis perlakuan memiliki nilai yang beragam. Jumlah $\mathrm{CO}_{2}$ yang dihasil berkisar dari 1,98-9,86 mg/hari/100 gram tanah. Dosis perlakuan yang memiliki nilai tertinggi adalah perlakuan K3A2 (pupuk kandang sapi 90 gram dan arang kayu $40 \mathrm{~g}$ ) sebanyak 9,86 mg/hari/100 gram tanah. Hal tersebut menunjukkan bahwa dosis perlakuan perlakuan K3A2 (pupuk kandang sapi 90 gram dan arang kayu $40 \mathrm{~g}$ ) memberikan hasil yang optimal terhadap jumlah $\mathrm{CO}_{2}$ oleh mikroorganisme yang ada didalam tanah. Hal ini terjadi karena peemberian pupuk kandang sapi dan arang kayu dapat memperbaiki kondisi tanah tanah yang rusak akibat kontaminasi oli bekas dan memberikan tempat tumbuh yang baik bagi mikroorganisme pada tanah.

\section{Hasil Analisis Tanah}

Media tanam yang digunakan pada penelitian ini adalah tanah yang telah dicemari oli bekas. oli bekas mengandung logam berat ( $\mathrm{Fe}, \mathrm{Pb}, \mathrm{Sn}, \mathrm{Cd}, \mathrm{Mn}, \mathrm{Zn})$ atau senyawa yang bersifat toksik seperti: Poly Chlorinated Biphenyls (PCBs) dan Polycyclic Aromatic Hydrocarbons (PAHs) yang memiliki sifat yang sangat sulit untuk terdegradasi dilingkungan (Welan et al. 2019). Pencemaran oleh oli bekas menyebabkan kerusakan bagi tanah sehingga tidak sesuai untuk pertumbuhan tanaman. Kerusakan tersebut dapat diperbaiki melalui pemberian bahan organik berupa pupuk kandang sapi dan arang kayu sehingga dapat pulih secara bertahap dan meningkatkan kesuburan tanahnya. Kesuburan tanah adalah potensi tanah untuk menyediakan unsur hara dalam jumlah yang cukup dalam bentuk yang tersedia dan seimbang untuk menjamin pertumbuhan dan produksi tanaman yang optimum (Yamani 2010). Hasil uji laboratorim analisis kimia media tanam sebelum dan sesudah diberikan pupuk kandang sapi dan arang kayu pada bibit salam dapat dilihat pada Tabel 6 .

Berdasarkan hasil uji laboratorium pada Tabel 6, terlihat bahwa terjadi perubahan parameter kimia tanah pada tanah kontrol yang dicemari oli bekas dengan tanah yang diberikan perlakuan pupuk kandang sapi dan oli bekas. Perubahan yang terjadi adalah perubahan secara kuantitatif pada setiap parameter yang dianalisis ada yang terjadi peningkatan dan ada juga yang terjadi penurunan. Parameter yang pertama yang memperlihatkan perubahan adalah $\mathrm{pH} \mathrm{H}_{2} \mathrm{O}$ pada kedua tanah. Tanah kontrol yang dicemari oli bekas memiliki nilai $\mathrm{pH}$ sebesar 4,34 dan tergolong sangat masam. $\mathrm{PH}$ merupakan reaksi tanah yang menunjukkan kemasaman atau alkalinitas tanah. $\mathrm{pH}$ tanah berperan penting dalam menentukan mudah tidaknya unsur-unsur hara diserap oleh tanaman. Unsur hara pada umumnya dapat diserap dengan baik oleh tanaman pada $\mathrm{pH}$ netral. Mikroorganisme tanah dan jamur dapat berkembang

Tabel 6 Hasil analisi sifat kimia tanah

\begin{tabular}{|c|c|c|c|c|c|c|}
\hline No & Parameter & $\begin{array}{c}\text { Tanah } \\
\text { kontrol }\end{array}$ & $\begin{array}{c}\text { Kriteria } \\
(*)\end{array}$ & $\begin{array}{c}\text { Pupuk kandang } \\
\text { sapi dan arang } \\
\text { kayu }\end{array}$ & $\begin{array}{c}\text { Kriteria } \\
(*)\end{array}$ & Perubahan \\
\hline 1 & $\mathrm{pH} \mathrm{H} \mathrm{H}_{2} \mathrm{O}$ & 4,34 & Sangat masam & 5,95 & Agak masam & $+1,61$ \\
\hline 2 & C-Organik $(\%)$ & 4,78 & Tinggi & 6,31 & Sangat tinggi & $+1,53$ \\
\hline 3 & N-Total $(\%)$ & 0,12 & Rendah & 0,14 & Rendah & $+0,02$ \\
\hline 4 & P-tersedia (ppm) & 1,21 & Sangat rendah & 2,39 & Sangat rendah & $+1,18$ \\
\hline 5 & $\mathrm{Ca}(\mathrm{me} / 100 \mathrm{~g})$ & 1,43 & Sangat rendah & 5,17 & Sedang & $+3,74$ \\
\hline 6 & $\mathrm{Mg}(\mathrm{me} / 100 \mathrm{~g})$ & 0,16 & Sangat rendah & 1,45 & Rendah & $+1,29$ \\
\hline 7 & $\mathrm{~K}(\mathrm{me} / 100 \mathrm{~g})$ & 0,14 & Rendah & 1,99 & Sangat tinggi & $+1,85$ \\
\hline 8 & $\mathrm{Na}(\mathrm{me} / 100 \mathrm{~g})$ & 0,07 & Sangat rendah & 0,57 & Sedang & $+0,50$ \\
\hline 9 & KTK (me/100g) & 13,24 & Rendah & 13,54 & Rendah & $+0,30$ \\
\hline 10 & $\mathrm{~KB}(\%)$ & 13,52 & Sangat rendah & 67,77 & Tinggi & $+54,25$ \\
\hline 11 & $\mathrm{Al}(\mathrm{me} / 100 \mathrm{~g})$ & 2,28 & & $\operatorname{tr}$ & & $-2,28$ \\
\hline 12 & H (me/100g) & 0,65 & & 0,10 & & $-0,55$ \\
\hline 13 & $\mathrm{Fe}(\mathrm{ppm})$ & 9,15 & Cukup & 9,17 & Cukup & $+0,02$ \\
\hline 14 & $\mathrm{Cu}(\mathrm{ppm})$ & 2,43 & Cukup & 3,54 & Cukup & $+1,11$ \\
\hline 15 & $\mathrm{Zn}(\mathrm{ppm})$ & 28,72 & Cukup & 18,25 & Cukup & $-10,47$ \\
\hline 16 & $\mathrm{Mn}(\mathrm{ppm})$ & 38,38 & Cukup & 27,36 & Cukup & $-11,02$ \\
\hline 17 & $\mathrm{~Pb}(\mathrm{ppm})$ & 2,30 & & 1,87 & & $-0,43$ \\
\hline \multirow[t]{4}{*}{18} & Tekstur $(\%)$ & & & & & \\
\hline & Pasir & 2,69 & & 1,46 & & $-1,23$ \\
\hline & Debu & 11,07 & & 16,45 & & $+5,38$ \\
\hline & Liat & 86,25 & & 82,09 & & $-4,16$ \\
\hline
\end{tabular}

*= Kriteria penilaian sifat kimia tanah (LPT 1983) 
dengan baik pada $\mathrm{pH}$ di atas 5,5 jika kurang maka akan terhambat aktivitasnya. pH tanah yang rendah akan menyebabkan tanaman tidak dapat memanfaatkan N, P, $\mathrm{K}$, dan zat hara lain yang dibutuhkan.

Parameter selanjutnya yang terjadi peningkatan adalah C-organik yaitu sebesar $1,53 \%$ dan pada akhir pengamatan menjadi $6,31 \%$ atau tergolong sangat tinggi. C-organik menunjukkan jumlah bahan organik yang ada didalam tanah. Tingginya nilai $\mathrm{C}$-organik pada tanah perlakuan dikarenakan penambahan pupuk kandang sapi dan arang kayu, sehingga mempengaruhi tingginya kandungan bahan organik pada tanah tersebut. Seperti yang telah diketahui juga bahwa bahan karbon berasal dari bahan organik yang terdekomposisi (Bakri et al. 2016). kondisi C-organik yang tinggi dapat meningkatkan kesuburan tanah lebih khusus ketersediaan unsur hara mikro. Bahan Organik Tanah (BOT) juga mempunyai peran penting dalam memperbaiki sifat fisik, kimia, dan biologi tanah dan secara langsung akan mempengaruhi tingkat kesuburan tanah, selain itu kandungan bahan organik juga merupakan salah satu indikator tingkat kesuburan tanah (Gunawan et al. 2019).

Peningkatan juga terjadi pada unsur hara makro seperti $\mathrm{N}$, $\mathrm{P}$, dan $\mathrm{K}$. Unsur $\mathrm{N}$ meningkat dari $0,12 \%$ menjadi $0,14 \%$, unsur $\mathrm{P}$ meningkat dari $1,21 \mathrm{ppm}$ menjadi 2,39 ppm dan unsur $\mathrm{K}$ meningkat dari 0,14 me/100 gram menjadi 1,99 me/100 gram setelah diberi perlakuan. Hal tersebut memunjukkan bahwa pemberian pupuk kandang sapi dan arang kayu dapat meningkatkan ketersediaan unsur hara makro pada tanah yang telah tercemar oli bekas. Unsur nitrogen berperan dalam meningkatkan pertumbuhan vegetatif tanaman, kadar protein dalam tanah, perkembangbiakan mikroorganisme dan berfungsi untuk sintesa asam amino, protein serta pembentukan klorofil pada tanaman.

Unsur hara mikro seperti $\mathrm{Fe}, \mathrm{Cu}, \mathrm{Zn}$ dan $\mathrm{Mn}$ juga mengalami perubahan. Unsur $\mathrm{Fe}$ dan $\mathrm{Cu}$ mengalami peningkatan sedangkan unsur $\mathrm{Zn}$ dan $\mathrm{Mn}$ mengalami penurunan. Unsur hara mikro adalah unsur hara yang dibutuhkan oleh tumbuhan dalam jumlah yang kecil dan diperlu dalam meningkatkan pertumbuhan suatu tanaman tetapi jika dalam jumlah yang berlebih dapat menjadi racun sehingga mengganggu metabolisme pertumbuhan. Tetapi pada tanah tercemar oli bekas yang diberi perlakuan jumlah unsur mikro yang terdapat pada tanah masih dalam batas toleransi (termasuk kandungan unsur alami dalam tanah) walaupun ada 2 unsur yang mengalami peningkatan tetapi tidak dalam jumlah yang besar.

Berdasarkan Tabel 5, terlihat bahwa tanah yang tercemar oli bekas mengandung $\mathrm{Pb} 2,30 \mathrm{ppm}$ yang setelah diberikan perlakuan pupuk kandang dan arang kayu terjadi penurunan sebesar 0,43 ppm. Hal ini karena bahan organik dapat mempertahankan kehidupan mikroorganisme tanah dalam keadaan normal dan mempergunakannya sebagai sumber energi. Selain itu bahan organik juga dapat bereaksi dengan logam berat membentuk senyawa kompleks (organo metalic complex) sehingga dapat mengurangi sifat racun dari logam berat dan mencegah pergerakan ion logam berat agar tidak masuk ke dalam sistem jaringan tanaman (Stevenson 1982 dalam Hayati 2010). Pemerian arang kayu juga dapat mengatasi cemaran logam berat karena arang kayu memiliki area permukaan besar, kapasitas tinggi untuk menyerap logam berat dan berpotensi untuk mengurangi bioavailabilitas serta pelindian logam berat dalam tanah melalui adsorpsi dan reaksi fisikokimia lainnya (Park 2011). Arang kayu biasanya merupakan bahan basa yang dapat meningkatkan $\mathrm{pH}$ dan KTK tanah dan berkontribusi terhadap stabilisasi logam berat.

\section{SIMPULAN DAN SARAN}

\section{Simpulan}

Pemberian pupuk kandang sapi tunggal berpengaruh nyata terhadap parameter pertumbuhan diamater, berat basah total, berat kering total dan panjang akar bibit salam. Pemberian arang kayu tunggal hanya berpengaruh nyata terhadap parameter berat basah total bibit salam. Interaksi antara pemberian pupuk kandang sapi dan arang kayu berpengaruh nyata terhadap parameter pertumbuhan diamater, berat basah total dan panjang akar bibit salam. Dosis pemberian pupuk kandang sapi 90 gram dan arang kayu 40 gram memberikan respon terbaik pada parameter berat basah total dan panjang akar sedangkan pemberian pupuk kandang sapi 90 gram dan arang kayu 20 gram memberikan respon terbaik pada parameter diameter dan pemberian pupuk kandang sapi 90 gram memberikan respon terbaik pada parameter berat kering total. Pemberian pupuk kandang sapi dan arang kayu juga dapat menurunkan kandungan unsur logam berat $\mathrm{Pb}$ sebesar 0,43 ppm.

\section{Saran}

Pemberian pupuk kandang sapi 90 gram dan arang kayu 40 gram dapat digunakan dalam bioremediasi lahan yang tercemar oli bekas atau bahan limbah lain yang mengandung unsur yang sama karena dapat meningkat pertumbuhan tanaman.

\section{DAFTAR PUSTAKA}

Asbur Y, Rahmawati, Adlin M. 2019. Respon pertumbuhan dan produksi tanaman jagung (Zea mays L.) terhadap sistem tanam dan pemberian pupuk kandang sapi. Agriland $7(1): 9-16$. doi:https://doi.org/10.30743/agriland.v7i1.1243.

Bakri I, Thaha AR , Isrun. 2016. Status beberapa sifat kimia tanah pada berbagai penggunaan lahan di DAS Poboya Kecamatan Palu Selatan. Agrotekbis 4(1):16-23.

Bano EH, Natalia V, Hasiati W, Salu F, Soleman IS. 2020. Pemanfaatan oli bekas sebagai bahan bakar alternative pada redesigned stove dengan menggunakan blower dan pipa besi. Jurnal Kesehatan 13(1):67-70. doi:https://doi.org/10.32763/juke.v13i1.196. 
Bramasto Y, Putri KP, Suharti T, Agustina D. 2011. Viabilitas benih danpertumbuhan semai maerbau (Intsia bijuga O. Kunize) yang terinfeksi cendawan Fusarium sp. dan Penicillium sp. Tekno Hutan Tanaman 4(3):99- 104.

Gunawan, Wijayanto N, Budi SW. 2019. Karakteristik sifat kimia tanah dan status kesuburan tanah pada agroforestri tanaman sayuran berbasis Eucalyptus Sp. Jurnal Silvikultur Tropika 10(2):63-69.

Haase DL. 2008. Understanding Forest Seedling Quality: Measurements and Interpretation. Tree Planters's Notes 52(2):24-30.

Hanafiah KA. 2005. Dasar-dasar Ilmu Tanah. Jakarta: PT. Raja Grafindo Persada.

Harahap F. 2012. Fisiologi Tumbuhan : Suatu Pengantar. Medan: Unimed Pr.

Hasibuan RDS, Ansoruddin, Ningsi SS. 2018. Pengaruh pemberian berbagai media tanam dan pupuk pelengkap cair (PPC) terhadap pertumbuhan bibit tanaman lada (Piper nigrum L.) di polybag. Agricultural Research Journal 14(3):110117.

Hayati E. 2010. Pengaruh pupuk organik dan anorganik terhadap kandunganlogam berat dalam tanah dan jaringan tanaman selada. Jurnal Floratek 5:113123.

Intara YI, Sapei A, Erizal, Sembiring N, Djoefrie MHB. 2011. Pengaruh pemberian bahan organik pada tanah liat dan lempung berliat terhadap kemampuan mengikat air. Jurnal Ilmu Pertanian Indonesia 16(2):130-135.

Irmayanti L, Mariati M, Salam, Buamona R. 2019. Respon pertumbuhan bibit jabon merah (Anthocephalus macrophyllus (Roxb.) Havil) di Persemaian pada pemberian pupuk hayati dan kimia. EnviroScienteae 15(2):204-210. doi:http://dx.doi.org/10.20527/es.v15i2.6952.

Lutfiasari N, Dharmono. 2018. Keanekaragaman spesies tumbuhan famili Myrtaceae di Hutan Pantai Tabanio, Kecamatan Takisung, Kabupaten Tanah Laut. Prosiding Seminar Nasional Lingkungan Lahan Basah 3(1):186-190.

Maftu'ah E, Maas A, Syukur A, Purwanto BH. 2013. Efektivitas amelioran padalahan gambut terdegradasi untuk meningkatkan pertumbuhan dan serapan NPK tanaman jagung manis (Zea mays L. var. saccharata). J. Agron. Indonesia 41(1):16-23.

doi:https://doi.org/10.24831/jai.v41i1.7071.

Mahendra F. 2009. Sistem Agroforetri dan aplikasinya. Yogyakarta: Graha Ilmu.

Oktavian S, Malik A, Wahid A. 2019. Evaluasi pertumbuhan pohon di lokasirevegetasi lahan pasca tambang PT. Genba Multimineral Desa Molino Kecamatan Petasia Timur Kabupaten Morowali Utara. Jurnal Warta Rimba 7(1):47-51.

Park JH, Choppala GK, Bolan NS, Chung JW, Chuasavathi T. 2011. Biochar reduces the bioavailability and phytotoxicity of heavy metals. Plant Soil 348:439-451.

doi:https://doi.org/10.1007/s11104-011-0948-y.
Parnata A. 2010. Meningkatkan Hasil Panen dengan Pupuk Organik. Jakarta: PT. Agromedia Pustaka.

Pitrandjalisari V. 2009. Analisis kelayakan investasi penggunaan teknologi crudeoil system di Departemen Power Plant PT Newmont Nusa Tenggara. Jurnal Teknik Industri 10(2):109-113.

Prasaji R, Dewita CU, Santosa H. 2013. Pemanfaatan kombinasi fly ash batubara, alkilbenzenesulfonat, dan zeolit pada penjernihan minyak pelumas bekas dengan metode penjerapan. Jurnal Teknologi Kimia dan Industri 2(4):1-7.

Putri MYG, Wasis B, Winata B. 2019. Study of Syzygium polyanthum (Wight) Walp. growth on the ex-limestone mining soil with goat manure and NPK fertilizer increment. Earth and Environmental Science 394:1-7. doi:https://doi.org/10.1088/17551315/394/1/012019.

Riyanto AB, Patola E, Siswadi. 2013. Uji dosis dan frekuensi aplikasi pupuk urea terhadap pertumbuhan bibit jati putih (Gmelina arborea Roxb.). Jurnal Inovasi Pertanian 12(2):113.

Sapsuha R., Thomas A, Lasut MT, Rombang JA. 2015. Pengaruh pemupukan NPK terhadap pertumbuhan bibit jabon putih Anthocephalus cadamba (Roxb.) Miq. In Cocos 6(6):1-8.

Setiawan D, Niswati A, Sarno, Yusnaini S. 2016. Pengaruh sistem olah tanah dan aplikasi mulsa bagas terhadap respirasi tanah pada pertanaman tebu (Saccharum Officanarum L) tahun ke-5 plant cane di PT Gunung Madu Plantations. Jurnal Agrotek Tropika 4(1):99104.

doi:http://dx.doi.org/10.23960/jat.v4i1.1910.

Siregar P, Fauzi, Supriadi. 2017. Pengaruh pemberian beberapa sumber bahan organik dan masa inkubasi terhadap beberapa aspek kimia kesuburan tanah ultisol. Jurnal Agroteknologi FP USU 5(2):256-264. doi:https://dx.doi.org/10.32734/jaet.v5i2.15383

Sitompul SM, Guritno B. 1995. Analisis Pertumbuhan Tanaman. Yogyakarta: Gadjah Mada University Pr.

Sutanto R. 2001. Pencemaran tanah dan air oleh pestisida dan cara menanggulanginya. Jurnal Perlindungan Tanaman Indonesia 7(1):9-15. doi:https://doi.org/10.22146/jpti.10015.

Wahyu Purbalisa W, Triyani Dewi T. 2019. Remediasi tanah tercemar kobalt (Co) menggunakan bioremediator dan amelioran. Jurnal Tanah dan Sumberdaya Lahan 6(2):1237-1242. doi:http://dx.doi.org/10.21776/ub.jtsl.2019.006.2. 4.

Wasis B, Fathia N. 2010. Pengaruh pupuk NPK terhadap pertumbuhan semai gmelina (Gmelina arborea Roxb.) pada media tanah bekas tambang emas (tailing). Jurnal Silvikultur Tropika 2(1):14-18. 
Welan YSL, Refli , Mauboy RS. 2019. Isolasi dan uji biodegradasi bakteri endogen tanah tumpahan oli bekas di Kota Kupang. Jurnal Biotropikal Sains 16(1):61-72.

Winarso S. 2005. Kesuburan Tanah Dasar Kesehatan dan Kualitas Tanah. Yogyakarta: Gava Media.

Yamani A .2010. Kajian tingkat kesuburan tanah pada Hutan Lindung Gunung Sebatung di Kabupaten Kota Baru Kalimantan Selatan. Jurnal Hujan Tropis 11(29):32.
Yolantika H, Periadnadi, Nurmiati. 2015. Isolasi bakteri pendegradasi hidrokarbon di tanah tercemar lokasi perbengkelan otomotif. Jurnal Biologi Universitas Andalas 4(3):153-157. doi:https://doi.org/10.25077/jbioua.4.3.\%25p.2 015.

Zam SI. 2011. Bioremediasi tanah yang tercemar limbah pengilangan minyak bumi secara in vitro pada konsentrasi $\mathrm{pH}$ berbeda. Jurnal Agroteknologi 1(2):1-8. doi:http://dx.doi.org/10.24014/ja.v1i2.50. 